\title{
Arielism Versus Cosmopolitanism: Brazilian Reaction to 9/1 1/01 as Cultural Narrative and Identity Work
}

\author{
Laura Robinson \\ Santa Clara University and Harvard Berkman Klein Center for Internet \& Society - laura@laurarobinson.org
}

\begin{abstract}
This research examines identity work vis-àvis Brazilian discourse regarding the events of September 11, 2001. The data is drawn from Brazilian nationals and expatriates participating in a digital discourse forum hosted by the newspaper O Estado de São Paulo. In discussing the events of 9/11/01, Brazilians also make sense of what it means to be Brazilian and what it means to be human. As the data show, Brazilians frame their reactions by drawing on larger understandings of the social world. The two most dominant stances come from Brazilians adopting what can be called Arielist and cosmopolitan stances. In addition, a small group of Brazilian expatriates join the fray as self-proclaimed Americanophiles. In examining these dynamics, we see that identities result from the process of identity construction best

framed from a social constructionist perspective. In these three cases, identities emerge from interaction, engagement, and reaction to competing identity frames. Through the ongoing dialogue interactions, Brazilian participants implicitly make statements about their self-conceptions and visions of Brazil's place in the world during this historic event. Significantly, the complementary and oppositional stances in reaction to 9/11/01 continue to persist almost twenty years after the attacks in the ideological frameworks around national identities circulating in both Brazil and the U.S. at present. In this way, the discourse from 2001 foreshadows the impending political chasm between right and left in both Brazil and the United States and provides an impetus for future research.
\end{abstract}

Keywords: arielism, Brazil, identity, terrorism, discourse, digital interaction.

\section{Arielismo versus cosmopolitismo: a reação brasileira ao 1 1/09/01 como narrativa cultural e trabalho de identidade}

\section{Resumo}

Esta pesquisa examina o trabalho da identidade vis-à-vis o discurso brasileiro sobre os acontecimentos de 11 de setembro de 2001. Os dados são provenientes de brasileiros e expatriados participantes de um fórum de discussão digital organizado pelo jornal O Estado de São Paulo.
Ao discutir os eventos de 11 de setembro de 2001, os brasileiros também entendem o que significa ser brasileiro e o que significa ser humano. Como mostram os dados, os brasileiros enquadram as suas reações com base em entendimentos mais amplos do mundo social.

(C) The Author(s) 2021. Open access article published online by Interações: Sociedade e as Novas

80 Modernidades, ISSN: 2184-3929, at https://interacoes-ismt.com, under the terms of the Creative

Commons Attribution-NonCommercial 4.0 International Licence (https://creativecommons.org/

licenses/by-nc/4.0). 
As duas posturas mais dominantes vêm de brasileiros que adotam o que pode ser chamado de posturas arielistas e cosmopolitas. Além disso, um pequeno grupo de expatriados brasileiros entra na discussão como autoproclamado americanófilo. Ao examinar essas dinâmicas, vemos que as identidades resultam do processo de construção de identidade melhor enquadrado por uma perspetiva construtivista social. Nesses três casos, as identidades emergem da interação, engajamento e reação a estruturas de identidade concorrentes. Por meio das interações de diálogo em curso, os participantes brasileiros implicitamente fazem declarações sobre as suas autoconcepções e visões do lugar do Brasil no mundo durante este evento histórico. Significativamente, as posturas complementares e de oposição em reação ao 11/9/01 continuam a persistir, quase vinte anos após os ataques, nas estruturas ideológicas em torno das identidades nacionais que circulam atualmente no Brasil e nos EUA. Dessa forma, o discurso de 2001 prenuncia o abismo político iminente entre direita e esquerda no Brasil e nos Estados Unidos e fornece um impulso para pesquisas futuras.

Palavras-chave: arielismo, Brasil, identidade, terrorismo, discurso, interação digital.

\section{INTRODUCTION}

This research examines identity work vis-à-vis Brazilian discourse regarding the events of September 11, 2001. The data is drawn from Brazilian nationals and expatriates participating in a digital discourse forum hosted by the newspaper $O$ Estado de São Paulo. In discussing the events of $9 / 11 / 01^{1}$, Brazilians also make sense of what it means to be Brazilian and members of humanity. As the data show, Brazilians frame their reactions drawing on larger understandings of the social world. The two most dominant stances are articulated by Brazilians expressing Arielist and cosmopolitan stances. In addition, a small group of Brazilian expatriates join the fray as self-proclaimed Americanophiles.

The research addresses one of the core problematics in global studies of media, culture, and identity. It examines how individuals and groups craft context-dependent identities when interacting in digital venues. The work addresses these interrelated areas of inquiry by examining how Brazilian digital discourse forum participants draw upon offline cultural norms in online spaces and how these offline understandings are transformed through online interaction. By examining how individuals make sense of 9/11/01 as an event with global implications, this study ascertains how

1 In this chapter, September 11, 2001 is always referenced with the year 2001 to differentiate it from September 11, 1973, the day of Pinochet's coup d'etat in Chile. 
virtual forum participants simultaneously employ identity work to frame competing interpretations of the same event.

These findings shed light on both the past and the present. The contested identity work and spirit of dissent performed in these fora in 2001 finds their corollaries in more recent identity work sparked by the rise of populist movements in Brazil, the United States, and other countries. In this way, the chasms in identity-work that emerged around 9/11/01 may be seen as an ongoing process that is accelerating into the future. Therefore, this article provides an impetus for future research to understand the deeply rooted nature of ideological schisms that predate the current environment of crisis and polarization.

\section{SOCIAL CONSTRUCTION OF IDENTITY}

There is great debate on how collective identities and meanings are continuously generated (Fine, 1993; Goodwin, Jasper, and Polletta, 2000). However, this project treats identity construction from a social constructionist perspective. Within the social constructionist paradigm, the processes by which individual identities and collective identities are formed are analogous, both processes giving rise to revisable identities. (Beiner, 1999; Calhoun, 1994; Hall, 1996; Jenkins, 1996). Broadly speaking, the theoretical orientation for this research is drawn from Giddens' claims that identity becomes a reflexive project of self constitution for modern selves, and that the construction of collective identities simultaneously involves processes of affiliation, inclusion and differentiation (1991). From this perspective, collective identity is a "relational achievement" that is constantly being forged anew (Gergen, 2001), and for which the construction is never completed (Hall, 1996). As this indicates, this "relational achievement" must be understood in conjunction with historically specific developments and practices, because identities are constructed within historically situated social and institutional sites. "The unity, the internal homogeneity, which the term identity treats as foundational is not a natural, but a constructed form of closure (...) constructed through, not outside difference" (Hall, 1996, pp. 4-5). According to social constructionism, identities are not only revisable, but are essentially open-ended.

The way in which one constructs one's own identity is constrained and conditioned by the ways that others construct it. Every collective constructs its identity categories in dialogue with other collectives that are constructing their own identity categories. 
When a collective defines its own identity categories, it is also defining itself for other collectivities. Further, in claiming the identity attached to their collectivity, members of the collectivity internalize the identity categories originating within other collectivities, thereby remaking others' identity categories into their own (Jenkins, 1996). In this process, power differentials play a very important role. External identifications may be experienced by members of a collectivity as coercively imposed upon them against their will; constructed self-understandings may "crystallize" or respond to the coercive force of external identification (Brubaker \& Cooper, 2001).

Certain identities may be embraced by the actor, while other collective identities are imposed. However, the boundary between the two is not always clear. According to Brubaker and Cooper, "Self-identification takes place in dialectical interplay with external identification, and the two need not converge. External identification is itself a varied process. In the ordinary ebb and flow of social life, people identify and categorize others, just as they identify and categorize themselves" (2001, p.15). As the conflicting identity categories produced and imposed by forum members reveals, self identifications interact with identifications that are delivered by other social actors. Through interaction, these two forms of identification either reinforce or weaken one another. The social constructionist approach to identity highlights these processes of inclusion, affiliation, and differentiation that result in the formation of collective identities. Through this recursive process of identity formation, further divisions are inscribed, and new identity categories are created.

Processes of collective identity formation have long been of interest to scholars interested in political movements and disasters (Fominaya, 2007; Fominaya, 2010; Fominaya \& Feenstra, 2020; Harvey, 2017). However, relatively few have targeted the role of media in the complex relationships between identity formation and terrorist events. A few notable exceptions include Fominaya's work on the 2004 Madrid bombings. According to Fominaya and Barberet (2013), the politics of victimhood is central to different understandings of terrorist acts, the roles of victims, and the roles of perpetrator. While these concepts are central to previous treatments of 9/11/01 and identity formation, very few studies have analyzed these processes in the case of Brazil.

According to Lasmar (2020), post-9/11 Brazil has not positioned itself as a key player in the global "war on terrorism." According to other studies, (Robinson, 2005; Robinson, 2008; and Robinson, 2009), identity work in reaction to the attacks has been marked by anti-American, anti-anti-American, and pro-American identity 
work in Brazil, France, and the United States. As these previous studies show, the negotiation of these identities takes place through moral metaphors including Lakoff's (2002) concepts of retribution and absolute goodness. Finally, these ideologically driven identity camps and constructions have remained stable over time many years after the initial attacks in 2001 (Robinson, 2017).

\section{OVERVIEW OF THE CASE STUDY, DATA, AND METHODS}

This chapter explores how these identity processes take place in discourses generated in response to $9 / 11 / 01$. The data are drawn from the 1844 posts generated in $O$ Estado's forum in the fall of 2001. This forum was chosen as it was the only national daily Brazilian newspaper with a forum dedicated specifically to these events. Entitled "The First War of the Century," the forum was open twenty-four hours per day, seven days per week from September 11, 2001 through October 29, 2001. During this time, the Brazilian forum received 3000\% more activity than other forum hosted by the site. Forum staff reports that response to $9 / 11 / 01$ is a defining moment that ignites record participation in the newspapers online discussion spaces. The sampling frame is all 1844 posts or contributions to the forum from September 11, 2001 through October 29, 2001, when the forum ends. Each day's postings were recorded in a digital format that preserves the sequencing experienced by the participants. In addition to forum posts, I conducted interviews in São Paulo with members of each forum staff.

Regarding the forum populations, the present research examines how individuals in online spaces make meaning through digital interaction: how they read others' presentations of self and react to them. While it was impossible to obtain socio-demographic information for the forum' user populations, it should be stated that there is reason to believe that the forum population most likely came from the economically privileged classes in Brazil. While the forum was open to the public and freeof-charge, only those individuals who had the economic means to use or acquire a computer, the phone toll costs, and the internet service provider fees could truly participate. In 2001, these were relatively costly barriers to participation making it likely that only the upper-middle classes truly had the opportunity to participate in O Estado's forum. 
Concerning analysis, in order to advance it at the semantic level, I exploit the techniques of "frame" analysis devised by researchers studying offline political discourse (Gamson, 1992). In this way I combine coding with more interpretive approaches. Traditionally coding schemes accommodate only "objective" coding categories such as direct reference, interactivity, and illocutionary status (Stromer-Galley \& Martinson, 2004). Issue frames elude such coding schemes and require an interpretive strategy aimed at teasing apart the meanings of the various underlying frames used by individuals. Here I take my cue from the work done by cultural sociologists interested in offline discourse on political topics (Fisher, 1997) and political sociologists who use frames to analyze multi-party exchanges regarding controversial political issues such as nuclear power and the Israeli-Palestinian conflict (Gamson, 1992). I employ the concepts of positions and frames in my interpretive analysis of forum discourse. Three primary identity frames emerge from the discourse: Arielist, cosmopolitan, and Americanophile.

Finally, a few notes regarding my translations of text from the Portuguese originals are in order. All names and user handles have been replaced with pseudonyms. Any historical or factual errors in posts are left uncorrected. Any politically incorrect, profane, or other objectionable terminology is also translated or transcribed from the original text. For example, the term "third world" or any of its variations is a direct translation of the original Portuguese text that stays true to the original, as are the terms "developed" or "developing countries." Some of the statements are objectionable as is recognized by the participants themselves who accuse their rivals of making unacceptable statements. Any and all statements made by participants are translated to participants' voices and points of view-they in no way indicate my personal views.

\begin{abstract}
ANALYSIS
As the analysis reveals, Brazilians discussing the events of 9/11/01 primarily draw on Arielist, Cosmopolitan, and Americanophile frames. Brazilian Arielists critical of the U.S. frame their own identities in terms of the damages done by the United States. By contrast, Brazilian cosmopolitans situate their identity as members of humanity as a supranational collectivity. Finally, a small group of Brazilian expatriates living in the United States express distinctly Americanophile identity framings.
\end{abstract}




\section{Arielism}

In immediate response to $9 / 11 / 01$, much of the discourse on the forum is critical of the United States and interprets the events of 9/11/01 as the result of a mosaic of American wrongdoings. This angle of vision stems from a larger Arielist framework. Arielism is based on an essay by José Enrique Rodó, the Uruguayan writer, at the turn of the nineteenth century (Yúdice, 2004). Rodós essay is drawn from Shakespeare's The Tempest and reinterprets some of the main characters as symbolic representations of the United States and Latin America.

In this play, Caliban is a monstrous figure, in contrast to the spirit Ariel who represents natural goodness and liberty. For Arielists, the United States takes the role of Caliban, brutal, uncivilized, and treacherous. This interpretation dovetails with Arielist critiques of American "utilitarianism" (Yúdice, 2004) that threatens elements of Brazilian culture. Those espousing the Arielist framework traditionally characterize the United States as the evil Caliban and Brazil (or Latin America) as the innocent spirit Ariel. Social actors relying on this framework place the United States in the role of Caliban that is synonymous with malevolence towards the rightful order. Within this framework, Ariel is always framed as an agent for good, while Caliban is always judged as the powerful evildoer. McPherson (2003) argues that such Arielist interpretations may go so far to equate powerlessness with virtue and to equate power with depravity.

From this general framework, Brazilian Arielists apply these interpretations to the specific events of 9/11/01. In the hours and days following the attacks, Arielists symbolically extend the characterization of powerlessness to all those harmed by the United States since World War II. For them, The United States is a global Caliban responsible for the thousands of civilian deaths due to military engagements since World War II. Arielists frame American foreign policy as an ongoing onslaught directed at multiple Ariels. They buttress this interpretation by causal logic attributing blame to the United States for military and economic violence done to countries around the world through American foreign policy:

(...) North Americans ${ }^{2}$ commit terrorism by calling it defense, bomb schools, kill civilians (...) now they feel it in their own skin what it means to bomb a

2 Some Arielists employ the terms "North American" or "Unitedstatesien" to replace "American." 
country, what it means to be on the receiving end of the intolerance they created themselves. When will this hypocrisy stop? They are the largest arms dealers dollar for dollar (...)

\section{Another writes:}

Americans have made themselves into the world's sheriff. Without anyone's leave, they attack any country as a preventative measure before even deciding if they are right or wrong. If we look at history we will see that the authors of this act could be Japanese to avenge Hiroshima and Nagasaki (...) could be Lebanese to avenge the death of Kadafi's daughter (...) But particularly the Palestinians would be right to react this way (...) they [Americans] see the world through the arrogance of the powerful, they had to believe that one day they would pay for this (...)

These Arielists collectively envision the United States' foreign policy since the 1940s as repeatedly using preventative strikes without establishing others' culpability. They see a world in which many collectives who have been wronged through preemptive strikes desire to avenge themselves. Symbolically, they describe many Ariels united against the evil Caliban. For these reasons, Arielists believe that damaged parties would be justified in reacting.

In addition to referencing foreign policy as blameworthy, Arielists also refer to covert actions by the CIA, including the CIA's operations in South America contributing to the rightwing coup détat that took power in 1964. Such individuals draw attention to what they perceive as the disconnect between the United States' claim to represent liberty and its covert activities that aided the military dictatorship:

The country of liberty and democracy sponsored dictatorships in all of Latin America and the world, from the coups détats to the subsequent assassinations, exiling, and torture. They sponsored them using the argument that they were defending liberty (...) In sum, official Unitedstatesien terrorism was also seen as legitimate through its propaganda and by the Western press as the defense of "democracy and liberty" (...) perhaps it would be a good time for the Unitedstatesien people to reflect on their state's bellicose foreign policy. 
Highlighting the paradoxal character of the foreign policy of the United States, as the self-described country of liberty that sponsors dictatorships abroad, Arielists blame the United States for the decades of military rule in South American countries, including Brazil. For them, the United States is directly responsible for the assassinations, exile, and torture practiced by the right-wing dictatorships in this continent. They contend that American arguments about democracy and liberty are in reality propaganda that seeks to legitimize "Unitedstatesien terrorism." Therefore, they argue that the 9/11/01 attacks should force Americans to reevaluate their country's aggressive covert activities that should be unmasked as "terrorism":

(...) the same United States that called itself democratic and a friend of liberty, financed, trained, and helped the implantation of political repression in Brazil, the Escola Superior de Guerra, ${ }^{3}$ was created under the supervision and in the image of the American model (...) the terrorism that must be combated above all is political and economic (...)

In referring to the Brazilian military dictatorship as aided and abetted by the CIA, these individuals implicitly frame a rupture between American rhetoric defining the United States as a democratic defender of liberty and its CIA activities in South America. Moreover, in so doing, they bolster important Arielist arguments that link foreign policy to economic injustice by equating terrorism with any and all American activities employed to strengthen the United States' political and economic agendas.

In addition, they make critiques of economic despotism as another way the United States acts as Caliban. Long before 9/11/01, Latin Americans critical of the United States have done identity work based on inclusion and exclusion to define the worthy and the unworthy (McPherson, 2003). This is especially salient in terms of larger arguments that link the United States' military and economic agendas (Ross \& Ross, 2004). Arielists believe that covert activities, foreign policy, and military engagements are part of the United States' goal to maintain economic despotism over developing nations. Arielist Brazilians indict the United States government for wronging other countries and non-American collectives through what they see as the unjust wielding of American economic power:

3 For those unfamiliar with Brazilian culture, the Escola Superior de Guerra is a federal institution of higher education for military training in Brazil; this individual compares it to the National War College in the United States. 
Hunger is the true violence done to humanity. But not just in Africa, there are other countries (...) All of the American governments and some of its populations are guilty, those that do not understand other cultures and believe that everyone must obey them, including Africans, Asians, and those of us in South America. We live in hunger and eternal economic crisis because of the guilt of the UNITED STATES OF AMERICA.

For Arielists, the United States is culpable of bringing violence to humanity by regularly forcing less powerful nations-other Ariels--into submission. As less powerful Ariels, they are constrained to live in abject conditions in order to enrich the United States in its capacity as a malevolent Caliban.

Moreover, they update the Arielist agenda in terms of globalization as a new form of power relations oppressing the virtuous or powerless nations. For them, the economic crisis imposed on developing countries is interpreted as part and parcel of the unilateral globalization forced on the world by the United States to exploit others:

The terrorist act committed against the biggest symbols of American military and economic power marks a new and maybe definitive turn in the world conflict between nations that are oppressed and exploited (...) the NEW WORLD ORDER dictated by the G7 countries (...) this new world is being GLOBALIZED UNILATERALLY (...)

For these Brazilian Arielists, globalization is a tool that allows developed nations led by the United States to oppress developing nations. Guided by the United States, these economically powerful Calibans oblige relatively powerless developing states to submit to their will to their own detriment. Such Arielists believe that the United States uses globalization in order to impose what they define as a new world order without regard to other nations or peoples.

Significantly, Arielists connect their critiques of foreign policy to these economic arguments. For them, American military acts are part and parcel of the United States' economic tyranny: both are interpreted as tools used by the United States to pursue its own interests as the global hegemon. Arielists believe that American economic imperialism is guilty of everyday genocide and death around the world. For them, the deaths caused by the 9/11/01 are but a drop in the bucket compared to those caused by the United States through its economic and foreign policies: 
The U.S.A. has always killed people everywhere to a far greater degree than the terrorists, and in the same way or through worse acts. Black people, poor people, innocent people that do not even know that they are killed by Americans with their protectionist laws, globalization, wars incited to sell arms, which is their big business.

Arielists believe that Americans create protectionist laws that are yet another fang of globalization that results in countless deaths, as do the wars that they think the United States brings into being simply to promote its arms industry. From the Arielist perspective, 9/11/01 creates an opportunity to remind the world that American economic gain is fueled by foreign policy seeking to protect American interests. This frame of American economic terrorism links together protectionist laws, globalization, and arms industries that Arielists describe as being actively wrought by the United States, producing economic destruction in developing countries. According to these Arielists, one cannot divorce economic and political motives, as one individual expresses: “(...) let us see these facts as a lesson. As is notorious, the U.S.A. maintains a highly interventionist foreign policy with the goal of protecting its economic prosperity (...)" Arielists believe that the United States actively seeks to bolster its economic agenda through interventionist foreign policies without any regard to its victims. From this standpoint, they argue that because the United States is guilty of promulgating foreign policy backing economic interests, 9/11/01 must be understood as a strike against politically upheld economic terrorism.

In parallel, these Arielists use analogies such as that of David and Goliath. Framed as a liberation from the long subjection to the American Caliban, 9/11/01 takes on a carnivalesque quality in the sense that power relations are turned upside down. On 9/11/01, Caliban has been made weak, and Ariel has been made strong. The attacks thus serve as a warning:

Let this attack serve as a warning to American leaders that no one is invulnerable, omnipotent, or omnipresent. No one on earth! No one is stronger than another just as David destroyed Goliath. Let this make Americans more respectful of the weak and the oppressed.

From this point of view, there is a fundamental imbalance in the globalized world created by American lack of respect of the weak and oppressed. Arielists hope that 
the United States will stop oppressing others now that it finds itself on the receiving end of violence. They express satisfaction and concur that the United States will be forced to re-evaluate its economic and political policies, "The world must change from now on. Globalization must change certain ideas and respect every country's needs." For them, Caliban is finally forced to examine the error of his ways:

I believe that the American government may still suffer more losses if it does not revise its leadership in this world in the process of globalizing. Furthermore, such globalization can only lead to a "unified hand" favoring the U.S.A.(...) What kind of world is this in which one sole Country can glorify itself to the detriment of so many other nations?

Another writes: "American foreign policy must change. Political and economicoppression pushed by the U.S.A., that arrogantly treats everyone like its backyard, rouses much hatred against this country." For Arielists, if the United States does not cease to trample the rights and injure the welfare of developing nations in the ruthless pursuit of profit and political power, it will continue to be the victims of Ariels who cease power to balance the moral scales.

\section{Cosmopolitanism}

While popular, Arielism is not the only discourse employed by Brazilians discussing $9 / 11 / 01$. In this case, some individuals identify with supranational imaginary communities as salient "imaginary communities" (Anderson, 1991). In the week following September 11, 2001, Brazilians also express their horror at the violence of the attacks whether or not they like the United States. These Brazilians adopt a cosmopolitanism stance critiquing the attacks because they are damaging to supranational identity categories such as "humanity."

According to Beck, there is an increasing shift towards the use of cosmopolitan identities via transnational social networks that transcend national boundaries (2000). Tomlinson also identifies the salience of cosmopolitan identity frames that may take the form of universalizing cosmopolitanism or pluralizing cosmopolitanism in reference to the globalization of culture (2000, p. 406). While a number of scholars have discussed varying facets of cosmopolitanism (Szersynskiand and Urry, 
2002), according to Kleingeld and Brown (2002), the most common cosmopolitanism is "moral cosmopolitanism." At the most inclusive level of definition, moral cosmopolitanism is the "moral ideal of a universal human community" (Kleingeld and Brown, 2002) that involves the capacity to live ethically both globally and locally (Tomlinson, 1999). It is this moral cosmopolitanism that is most widely embraced by Brazilians discussing 9/11/01.

Cosmopolitans challenge Arielists by constructing different interpretations of the events of 9/11/01. Cosmopolitans envision responsibility for the attacks in terms of humanity and the human condition. For these individuals, the events of 9/11/01 demonstrate the worst of which humankind is capable. They frame humanity as trapped by the human condition and, therefore, collectively guilty of the attacks. Finally, in contrast to Arielist insistence on political interpretations, cosmopolitans express greater concern regarding the victims' suffering, as well as the families' anguish in losing loved ones.

When confronted by Arielists applauding 9/11/01, cosmopolitans explicitly denounce the Arielist framework as immoral. Regarding economic despotism, for cosmopolitans, it is illogical to make this connection because economic inequalities are not related to the events of $9 / 11 / 01$ :

Do you know what this is? 30 years of Propaganda in Brazil saying that all poor people are good guys and all the rich are Machiavellian creatures that have meetings every night to plan how they will go exploit the innocent and honest ones who have no money. We know this isn't truth. It is always good to remember that in Brazil, the rich are those of us participating in this forum (...) or are all of us evil beings that are going to hell (...)

Cosmopolitans refute claims of economic despotism as "propaganda." For them, Americans are as guilty of being Calibans as are the economically privileged participants in the Brazilian forum. On a larger level, they argue that economic dominance and manipulation is a failing common to all of those with power: "It is pure hypocrisy to mourn for the victims and, at the same time, believe that what happened in the United States was deserved. Arrogance is inherent in all of the rich, independent of their origins." In making these arguments, cosmopolitans declare the powerful of any nation as equally responsible for the wellbeing of the economically powerless.

In like manner, cosmopolitans state that the Arielist stance regarding foreign pol- 
icy and loss of life is hypocritical. Cosmopolitans point to the double standard that implicitly gives some lives more value than others:

What I see in this forum is that many compare wars in Kosovo, Bosnia and others that happened with the terrorist attacks that occurred in the United States. When they do it, they pointedly put a feeling of "revenge" against the Americans into their words. In reality, the majority do not perceive that in making these comparisons many of them are really saying that the death of one person from a poor country should have greater value than the life of one wealthy American.

For these individuals, Arielists do not grasp the significance of 9/11/01 because their reactions are based on political views and arguments conceived a priori to the events. Cosmopolitans repeatedly uphold the sanctity of life for people of all nationalities.

In keeping with this framework, cosmopolitans believe that, if the sanctity of life is equal for all peoples, all victims will be shown compassion. For this reason, cosmopolitans register moral indignation in response to Arielist satisfaction:

I am shocked by what has happened in the U.S.A. and yet even more so by what I have read in this forum. Anyone with a conscience should mourn the death of thousands of civilians and ask God to comfort the families of the unfortunates. But there are people who manage to see this act of insane terror as something good. As if it were deserved! How can these people deserve to die!

These cosmopolitans see Arielist satisfaction as unconscionable: "It is amazing that in such a time people can put forward reasons to justify such a barbaric act!" Further, cosmopolitans challenge them to remember the humanity of the victims' loved ones:

What kind of talk is this? The people that lost their lives deserved it? Simply by being American? Imagine the families' desperation looking for their relatives. They are lives and lives that were lost. How many fathers, family men, died, people who never think of political oppression. We should cry for this tragedy 
just as we should cry help people who die of violence in Brazil, who die in the drought of the Nordeste ${ }^{4}$, etc. We are all human (...) right?

In sum, cosmopolitans accuse Arielists of not having their priorities straight: "Some participants here valorize political stances more than the sanctity of human life."

Cosmopolitans also engage in larger commentaries on what it means to be a member of humanity. Certain individuals frame humanity as the ultimate symbolic perpetrator of $9 / 11 / 01$. Because humanity is capable of great evil, as members of humanity we are all guilty:

History repeats itself here like WWI and WWII. It looks like governments have not learned their lesson. What has happened is the fruit of greed, religion, politics, economics, in short what we call being human.

These arguments are anchored in a basic understanding of human nature as capable of great wrongdoing as one individual expresses, "Man, like hatred, is the worst of animals." Yet another individual expresses his shame at being human: "I believe that what I am thinking is not terribly different than what the rest of the world is imagining. We are ashamed to be part of the same race as those responsible for this!" Another asks:

Have we come to this point? How is it possible that the human race has decided to bring itself so low? I feel horrible. I would like to be any beast, even a crawling cobra rather than belong to such a barbaric species of animal!!! We are all guilty in this tragedy. We all carry within us the feelings of hatred and intolerance. What will we do next? More attacks, counter-attacks to the point of total annihilation?

Yet another individual expresses the following impression: "Horror... horror... horror... I feel shame to be a human being." As one individual summarizes, 9/11/01 is part of human suffering brought about by human hands: "Human beings are the greatest guilty party in all of this that has happened, for through global greed humanity respects no one, no even for its own shadow."

4 For those unfamiliar with Brazilian culture, the Nordeste is the North East region of Brazil. Like certain regions in the United States, this region of Brazil is often associated with great economic insecurity. 
Cosmopolitans believe that 9/11/01 marks a moment to reconsider what it means to be human. Brazilian cosmopolitanism represents this ideology as a pro-human stance that symbolically divides the world into human and inhuman acts:

When we experience days in which our feelings and actions are marked by perplexity, fear, sadness, discouragement, and insecurity, we are forced to reflect on what we have done, what we are doing, and what we are leaving for the next generations. It was not only the U.S.A. that was victimized in these attacks (...) all of humanity suffers the consequences of the inhuman acts committed today.

Like many cosmopolitans in the Brazilian forum, this person refers to the terrorist acts as "inhuman." Other individuals echo "An attack of these proportions demonstrates to the world the extreme treachery of these groups of terrorists (...) the death of thousands of people, innocent victims of this brutal attack is an inhuman act." Another rebukes the Arielists:

We are witnessing here one the most appalling events in contemporary history. After which followed a merry-go-round of burlesque and stoic reactions; there are some who applaud and those that are horrified and this inevitably elicits a reflection on the strange nature of humanity. Someone said that human beings are the only animal that will stop to watch a fire. In this line of thought, human beings are the only animal that will do many other things, such as believing it to be heroic and just that thousands of people died as victims of terrorist acts.

For cosmopolitans, regardless of nationality, each of us has the choice to be human or inhuman, a choice that they define as the ultimate identity marker:

It was truly a shocking event, without precedent in the history of the civilized world. For me it was obvious that there are two worlds that are absolutely different: the first is made up of people who are born and work for their neighbor, for society. People like us, who despite whatever difficulty, in the day-to-day struggle for what is best. The second type of being, which we cannot call human, only is born to grow up to sow hatred, destruction, unjustified death, in truth the horsemen of the Apocalypse who decide who will live and who will die. We 
must not allow ourselves to be influenced by this feeling of hatred and in turn create more destruction.

In sum, for cosmopolitans: "This war is horrible for all humanity. Mankind must unite and not kill himself in wars of this kind."

\section{Americanophilia}

Finally, a small cadre of Americanophiles join the melee. Not surprisingly, many are expatriates or have lived in the United States. These Americanophiles use many of the same arguments as cosmopolitans to reject Arielist stances. However, in addition, this small group vigorously champions the United States by making positive statements about the United States, its economy, its political system, its values, and its people. Further, these Americanophiles critique Arielists on a number of grounds, including what they frame as the veracity of their statements, their logic, and their hypocrisy. Significantly, many of these assertions emerge as responses to Arielist rhetoric that prompts Americanophiles to critique the Arielists of betraying Brazil by refusing to solve problems in their own country. For this reason, although Americanophiles may be loyal to Brazil and be proud of being Brazilian, they often use Brazil as a foil to the United States.

Americanophiles frame a disjuncture between Arielist hypocrisy and American agency. They accuse Arielists of concentrating on American wrong-doing, rather than critically evaluating their own responsibilities in Brazil:

Let's hide behind the story that we are poor miserable things, discriminated against by the U.S.A. who are the great villains, usurpers, thieves, exploiters (...) Until what point are we going to blame others for our own afflictions and disgrace. The Brazilian people's problem is to believe that it is competent, capable, and superior. "Oh but the U.S.A. is clipping our wings" If people were so competent and superior we would not still be a developing nation (...) People don't need Americans' help, no we are full of villains in our own house!

Americanophiles frame Arielists as hypocrites who routinely criticize Americans without acknowledging Brazil's own problems. 
Unhappily, many ignorant people who watched this unjustifiable act are celebrating -including in Brazil! As if the U.S.A. were responsible for us having an incompetent government and a people, in its majority, preoccupied with having fun (...) worried more about vacation, Carnival, and soccer) rather than taking a definitive position on issues concerning social justice (...) I am from São Paulo and have lived in Boston for six years and was critical of American thinking until I understood that "citizenship" is more than a word in the dictionary (...) We have other problems in the U.S. but nothing compared to the indifference that one sees in Brazil for example (...)

Americanophiles charge Arielists with blaming the United States for all of Brazil's problems without doing anything to help Brazil themselves: “(...) For those who consider Americans 'belligerent and bellicose' cast your eyes on your own morning newspaper and see the violence of your own people against your own people. Ah! Stop blaming society."

Americanophiles believe that this hypocritical disconnect is at the root of Arielist frames. Americanophiles argue that Arielists insist on irrationally considering the United States culpable no matter what it does. In addition to blaming the United States for Brazilian problems, they charge Arielists with blaming the United States for both action and inaction. Americanophiles frame Arielist arguments as a vicious circle in which the United States will be blamed for any decision:

Today it is easy to criticize the U.S.A. and to say simply that they are reaping what they have sown, but at the same time, in addition to wanting the U.S.A. to be a country that doesn't intervene in any way, economically, militarily, or culturally in any other country, we want them to be responsible for the hunger and AIDS in South Africa, for the hunger and drought in Brazilian Nordeste, for the hole in the ozone layer, for the destruction of the Amazon, for the senseless holy war in the Middle East, for the rising price of petroleum, and many other things(...)

Americanophiles argue that Arielists blame the United States as an imperialist for any economic, military, or cultural intervention in another country. At the same time, the United States is culpable for failing to solve world hunger, AIDS, and global warming. Americanophiles argue that the United States is put into an eternal catch 22 , alternately blamed for its power and blamed for not using its power. 
In addition, Americanophiles challenge the Arielist argument that if the United States were not so omnipresent, other countries would inevitably thrive:

The American people may be imperfect, but the reasons that many are writing about, the "justification" that the Americans "deserved," is the consequence and fruit of MUCH ENVY. I have lived in Los Angeles for 12 years and live with the American people. The United States, for those who are poorly informed, fought hard to have all that it does. Many complain about American society, but are very happy to have the opportunity to visit Orlando, Miami, Los Angeles, even New York. Therefore, for those who hide their envy with their irrational, heartless opinions, simplify your messages and say "I support what happened in New York because I am VERY ENVIOUS of the United States." I love Brazil passionately, but will not tolerate Brazilians who want to stick a knife into the United States without seeing (or better, DOING!!!) anything to better their own country.

Another adds that should the United States cease to be a superpower it would change nothing because Arielists would continue to fail their own country and simply find another Caliban to blame:

(...) should they [Americans] not share all of their inventions with the rest of the world, should they not be multi-national, spread into the entire world, polluting it with their rules, ideas, norms... Maybe then other countries would have the chance to grow, turn themselves into decent countries, to combat hunger, thirst, and the health of their peoples. Or perhaps some countries would continue to be just the same as they are today? Continue to look for someone to blame, their own countrymen, their government, or maybe God? Maybe one day they will finally get to the point of saying, "God leave me alone because you are suffocating me and I can't manage to be decent, rich, dignified, because you won't leave me alone, you are suffocating me!!” (...) in this forum there is a deep feeling of envy towards Americans. In the end, we would all like to be great, rich like they are, and feel great and rich (...)

For Americanophiles, Arielist rhetoric blames the United States for what it has done, what it has not done, and what it should have done. They charge Arielists with 
cloaking their "envy" by twisting anything to frame the Americans in a negative light consistent with their Arielist-Caliban understanding of the social world.

For these reasons, Americanophiles frame Arielists as not only ignorant but in denial and intent on deceiving themselves at their own peril, thereby potentially endangering Brazil:

Reading the posts here (...) I think Brazilians should limit their posts to soccer and carnival. They are very clever at those.(...)those that defend anti-American terrorism, just wait. Terrorism will arrive at your door before you can say "bye bye" (...) For those against arms: you just wait. The time will come when you will wish had one at your disposition. Such are ignorant people. They are against anyone more powerful, but in the moment of truth want their help. Ai! From their own ignorance they see others as hypocrites!

Even more important, Americanophiles assert that Arielists are potentially opening the doors to the terrorists who respect no one and may well target Brazilian cities next:

It was not only an attack against the U.S.A. It was an attack against anyone, any country that values law, order, and peace. Today it was New York City. One day in the future, it would be São Paulo, Belo, Rio or Recife. Those who want to blame President Bush simply do not understand what is at stake. These terrorists are religious fanatics who value death more than life (...) their own lives and the life of the entire world.

Another picks up this thread and argues that, were Brazil powerful like the United States, Arielist views of 9/11/01 would be transformed:

(...) we might even be a little arrogant, show the world that we were important, that to destroy a building here in Brazil with 20,000 people who die wouldn't go unnoticed, these 20,000 people who would be missed, because in the first place they would be human beings leaving families and friends, and probably the world would lose some brilliant minds. We would say that God gives life, so only he can take it away. We wouldn't think that it is normal that some crazy, envious, bitter person thinks he has the right to crash a plane and kill thousands of 
people. We would think that anyone trying to excuse this crazy, envious person (...) was crazy and envious. Only we don't have the courage to admit this. May the Lord be with us and guide those who died innocently to Paradise.

Finally, Americanophiles remind Arielists that Brazil itself is a powerful county that could be viewed as a Caliban by other Latin American countries casting themselves as Ariels confronted by a Brazilian Caliban:

Know that in Latin America, countries like Argentina, groups in Uruguay, Paraguay, Columbia, and Chile think the same things [about you] that you do respecting the United States. They nurture the same hatred for the Brazilian way of life. From one side of their mouths, Argentineans call us despots; from the other they call us idiots. What if one day one of these countries were to send a group of terrorists to destroy the Brazilian way of life. How would it be if afterwards, Latin American countries began to write in a forum like this one that "those terrorists were right because of Brazilian despotism"? (...)

For Americanophiles, Arielists are so determined to fit the events of 9/11/01 into their a priori agenda, they are putting Brazil at risk by failing to see that Arielist framework can be used to create a Brazilian Caliban.

\section{CONCLUSIONS}

The analysis has shown how three identity options are collectively constructed by members of the online discourse forum. In each case, each group treats identity as a reflexive project of self constitution in which members claim authority to speak for the collective. In each case, this claim to authority is challenged. Although they draw on complicated narratives, essentially all three groups reduce $9 / 11 / 01$ as a choice between two polar opposites. For Arielists, the choice is between the weak and powerful interpreted as the world versus the United States. For cosmopolitans, the choice is between humanity and inhumanity. For Americanophiles, the choice is between the

United States and the terrorists. All of these choices are based on the construction of "imagined communities" (Anderson, 1991) that are associated with the construction of symbolic collective identities. Each identity is the result of processes of affiliation, 
inclusion and differentiation as discussed by Calhoun (1994). Here it becomes clear that such identities are the result on interaction and dissensus underscoring Gergen's (2001) claim that identity must be seen as a "relational achievement," as well as Hall's claim that identities are transmutable: "a constructed form of closure (...) constructed through, not outside difference" (Hall, 1996, pp. 4-5).

In the case of Arielism, we see this process play out via identity work drawing parallels between Brazil and Ariel, the underdog protagonist who is faced with the United States as Caliban, the hegemon culpable of many of the world's problems. This vision of power relations drives Brazilian Arielist response to 9/11/01. In the case of $9 / 11 / 01$, Arielists extend this older framework to create identity bridges between all Ariels as the world at large as the innocent victim of Caliban or the United States. When Brazilian Arielists frame the United States as responsible for provoking the 9/11 attacks through political and economic terrorism, they draw the lines of "us" and "them" based on a priori definitions of power and powerlessness as markers of moral purity and moral impurity. Arielists frame the United States as driving the terrorists to commit what they frame as a coup of the dispossessed against their powerful oppressors. According to Arielists, the United States uses its foreign policy to enforce its economic supremacy as part of a global economic imperialist regime in which the United States regularly humiliates developing nations. Using this causal frame, these Arielists believe that this degradation is responsible for violent outbursts on the part of the humiliated. For such Brazilian Arielists, this humiliation is linked to the perceived low esteem in which the rest of the world is held by the United States; further it is a legitimate reason for violence and unrest. All of these framings serve the central identity project driving Arielist identity work that others the United States as the immoral them, set in opposition to the terrorists, the world's have nots, and the Arielist Brazilians claiming to speak for this collectivity.

By contrast, Brazilian cosmopolitans position themselves against Arielists by employing arguments about the sanctity of life for all peoples regardless of nationality. Whether or not they have negative opinions regarding the United States, these Brazilian cosmopolitans respect all lives lost on $9 / 11 / 01$ as human lives. They defend 9/11/01's victims as members of humanity, in many cases despite their American nationality. In many ways, expressions of cosmopolitan identity are an explicit reaction to the Arielists. Regardless of their disapproval of various aspects of the United States, individuals who are horrified by Arielist posts are quick to identify themselves in opposition to the Arielist stance. Doing so is significant as it valorizes the sanctity 
of human life as the most important identity frame dividing the human "us" from the "inhuman them." In so doing, they challenge Brazilian Arielists who claim that Americans have forfeited their membership in the human family by virtue of their government's foreign policies. Brazilian cosmopolitans counter that all humans must be considered members of the human family when human life and wellbeing are at stake, no matter what their governments may have done. Rather than refuting the claims of Arielists and denying their allegations of wrongdoing by the United States, they deploy the depoliticizing frame of global humanity. For cosmopolitans, the 9/11/01 attackers targeted fellow members of the human race. In so doing, the terrorists demonstrate the very worst of which humans are capable. Any attempt at excusing such conduct is unconscionable because it contravenes what they characterize as basic morality common to all.

While the previous arguments are largely put forth by Americanophile Brazilians who self-identify as living in Brazil, their arguments are also championed by a group of Brazilians living in the United States. Most of the Americanophiles live or have lived in the United States. Like cosmopolitans, Americanophiles make the distinction between imperfect foreign policy and terrorist agency. However, Americanophiles go further and refute what they consider to be Arielist revisionist history that casts American foreign policy as the culprit causing 9/11/01. For them, rather than embodying a monstrous Caliban, the United States is caught in a catch 22 in which it cannot be judged fairly. For this group of individuals, identity work is fraught with tensions. On the one hand, many are deeply attached to Brazil; as one writes: "I love Brazil passionately..." On the other hand, these Americanophiles are so appalled by Arielist discourse that they strike back by accusing Arielist of betraying Brazil. According to the Americanophiles, Arielists continue to waste their vital energies against an imaginary Caliban when they should be working to solve problems closer to home. Here they attempt to defend the United States but in so doing create an identity that on certain levels separates them from other Brazilians on the forum.

\section{IMPLICATIONS FOR THE PRESENT}

In examining these dynamics, we see how identities are socially constructed; identities are created via interaction, engagement, and reaction to competing identity frames. Finally, although these competing identity options are ostensibly a discussion 
of September 11, 2001, in many ways the ongoing debate is also a discussion of what it means to be Brazilian and even what it should mean to be part of humanity. As we have seen, through the ongoing dialogue interactions, Brazilian participants implicitly make statements about their self-conceptions and visions of Brazil's place in the world during this historic event.

Further, these discourses and identities have not lost their salience. On the contrary, almost twenty years after the 2001 attacks, the identity discourses emerging from reaction in 2001 have increased in explanatory power. At time of writing in 2021, despite its travails, Brazil's meteoric rise on the world stage continues. From Lula to Dilma to Bolsonaro, Brazil's rollercoaster political ride is emblematic of the deepening ideological divides in both Brazil and the U.S. As this indicates, the identity discourses alternately positioning Brazil or the U.S. as victim or hegemon may help understand the rapid rise of populist presidents Bolsonaro and Trump. Therefore, while Arielism has been associated with left-of-center politics, with the rise in rightof-center populist, its animating ideas may be useful to understanding the adoption of these identity narratives by Presidents Bolsonaro and Trump (Robinson, 2021).

\section{FUTURE WORK}

Twenty years after 2001, in 2021 we are now living in a much larger global crisis: the COVID-19 pandemic, which has ravaged Brazil and the U.S. alike. Like the attacks of 2001, reaction to the pandemic has been ideologically charged in both Brazil and the U.S. However, it has yet to be seen if roles in the Arielist scenario will be recast with new protagonists and antagonists. Going forward, scholars should ask questions including: Who will be the players on tomorrow's world stage? Will some Brazilians continue to self-identify using Arielist frameworks despite Brazil's increased power and the diminished power of the United States? Or will other Brazilians envision themselves as the new Caliban of Latin America or will this role continue to be the unique purview of the United States? Or will yet another post-pandemic scenario play out with China emerging as the global Caliban and those harmed by the pandemic as a new class of Ariels collectively harmed and helpless? Future work would do well to map out these discourses, identity stances, and positions in the post-pandemic world. 


\section{REFERENCES}

Anderson, B. (1991). Imagined communities: Reflections on the origin and spread of nationalism. London: Verso.

Beck, U. (2000). The cosmopolitan perspective: Sociology of the second age of modernity. British Journal of Sociology, 51(1), 79-105.

Beiner, R. (1999). (Ed.). Theorizing Nationalism. Albany, NY: State University of New York Press.

Brubaker, R., \& Cooper, F. (2001). Beyond identity. Theory and Society 29, 1-47.

Calhoun, C. (Ed.) (1994). Social theory and the politics of identity. Oxford, UK: Blackwell.

Fine, G. (1993). The sad demise, mysterious disappearance, and glorious triumph of symbolic interactionism. Annual Review of Sociology, 19, 61-87.

Fisher, K. (1997). Locating frames in the discursive universe. Sociological Research Online 2(3), 88-111.

Fominaya, C. F. (2007). Autonomous movements and the institutional left: Two approaches in tension in Madrid's anti-globalization network. South European Society and Politics 12(3), 335-358.

Fominaya, C. F., \& Barberet, R. (2013). Defining the victims of terrorism: Competing frames around victim compensation and commemoration in post-9/11 New York City and 3/11 Madrid. In Athina Karatzogianni (Ed.), Violence and war in culture and the media (pp. 129-146). London: Routledge.

Fominaya, C. F.. (2010). Collective Identity in Social Movements: Central Concepts and Debates. Sociology Compass, 4(6), 393-404.

Fominaya, C. F. (2020). Social movements in a globalized world. London: Red Globe Press.

Fominaya, C. F., \& Feenstra, R. A. (2020). Routledge handbook of contemporary european social movements. London: Routledge.

Gamson, W. (1992). Talking politics. Cambridge, UK: Cambridge University Press. 
Giddens, A. (1991). Modernity and Self-Identity. Stanford, CA: Stanford University Press.

Goodwin, J., Jasper, J., \& Polletta, F. (2000). The return of the repressed: The fall and rise of emotions in social movement theory. Mobilization: An International Quarterly, 5(1), 65-83.

Hall, S. (1996). Who Needs 'Identity'? In Stuart Hall \& Paul du Gay (Eds.),Questions of cultural identity Thousand Oaks, CA: Sage.

Harvey, D.C. (2017). Gimme a pigfoot and a bottle of beer: Food as cultural performance in the aftermath of hurricane Katrina. Symbolic Interaction, 40(4), 498-522.

Jenkins, B. (2000). French political culture: homogenous or fragmented? in William Kidd \& Sian Reynolds (Eds.), Contemporary French cultural studies. New York: Oxford University Press.

Kleingeld, P., \& Brown, E. (2002). Cosmopolitanism. In E. N. Zalta (Ed.), The Stanford Encyclopedia of Philosophy (Winter 2002 Edition). https://plato.stanford.edu/ archives/win2012/entries/cosmopolitanism/

Lakoff, G. (2002). Moral politics: How liberals and conservatives think. Chicago, IL: The University of Chicago Press.

Lasmar, J. M. (2020). When the shoe doesn't fit: Brazilian approaches to terrorism and counterterrorism in the post-9/11 era. In Michael J. Boyle (Ed.), Non-Western responses to terrorism. Manchester, UK: Manchester University Press.

MacDonald, P. K. (2018). America First? Explaining Continuity and Change in Trump’s Foreign Policy. Political Science Quarterly, 133, 402- 434.

McPherson, A. 2003. Yankee No! Anti-Americanism in U.S.-Latin American Relations. Cambridge, MA: Harvard University Press.

Robinson, L. (2005). Debating the events of September 11th: Discursive and interactional dynamics in three online fora. Journal of computer-mediated communication, 10(4), JCMC10412.

Robinson, L. (2008). The moral accounting of terrorism: Competing interpretations of September 11, 2001. Qualitative Sociology, 31(3), 271-285. 
Arielism Versus Cosmopolitanism: Brazilian Reaction to 9/1 1 /01

as Cultural Narrative and Identity Work

Robinson, L. (2009). Brazilian-US Communication Forum| Cultural Tropes and Discourse: Brazilians, French, and Americans Debate September 11, 2001. International Journal of Communication, 3(16), 652-667.

Robinson, L. (2017). Collective memory: September 11th now and then. Information, Communication \& Society, 20(3), 319-334.

Robinson, L. (2021). Canaries in the climate coal mine: Climate change and COVID-19 as meta-crisis. First Monday.

Ross, A., \& Ross, K. (Eds.). (2004). Anti-Americanism. New York: New York University Press.

Stromer-Galley, J., \& Martinson, A. (2004, September). Coherence or fragmentation?: Comparing serious and social chat online. Paper presented at the Association for Internet Researchers Annual Conference, Sussex, UK.

Szersynskiand, B., \& Urry, J. (2002). Cultures of cosmopolitanism. The Sociological Review, 50(4), 455-481.

Tomlinson, J. (2000). Proximity politics. Information, Communication and Society 3(3), 402-414.

Yúdice, G. (2004). Prepotencia: Latin americans respond. In Andrew Ross \& Kristin Ross (Eds.), Anti-Americanism. New York: New York University Press. 